\title{
Thalidomide promotes leukocytosis in mice inoculated with 4T1 mammary carcinoma
}

Talidomida promove leucocitose em camundongos inoculados com carcinoma mamário murino 4 T1 clínico

Diego Carlos dos Reis ${ }^{1}$; Cristina Maria de Souza²; Liliane Cunha Campos³; Ana Cândida Araújo e Silva ${ }^{4}$; Miriam Teresa Paz Lopes5; Geovanni Dantas Cassali ${ }^{6}$; Enio Ferreira ${ }^{7}$

\begin{abstract}
The aim of this study was to evaluate the therapy effect of thalidomide in the 4T1 murine mammary carcinoma. 4T1 cell suspension was injected into the posterior left flank of all animals to obtain solid tumors. Five days after inoculation, the treatment group was orally administered $150 \mathrm{mg} / \mathrm{kg}$ of thalidomide for seven days. Tumors were measured every 48 hours until the end of treatment. Whole blood was collected for hematology analysis. Our results suggest that thalidomide therapy increase the number of circulating leukocytes in the 4T1 murine mammary carcinoma, and this response is accompanied by a decrease in tumor growth.
\end{abstract}

Key words: mice; neoplasia; 4T1 tumor; thalidomide.

\section{INTRODUCTION}

Thalidomide is a synthetic derivative of glutamic acid, little soluble in water, found in the racemic mixture of two enantiomers that has immune and anti-angiogenic properties ${ }^{(6)}$. The mechanisms of action of this drug are not completely elucidated; its antineoplastic effect has been linked with the suppression of angiogenic factors, as the basic fibroblast growth factor (bFGF) and the vascular endothelial growth factor (VEGF) ${ }^{(2,5)}$, and the modulation of synthesis of tumor necrosis factor alpha (TNF- $\alpha$ ) and other cytokines essential for cell growth in the tumor microenvironment $^{(13)}$.

Clinical and experimental trials have demonstrated thalidomide activity in the control of multiple myeloma, multiform glioblastoma and solid tumors, and in malignant hematologic conditions. In spite of the satisfactory results of its use as an antineoplastic agent, several dose-dependent side effects contribute, in some cases, to treatment interruption ${ }^{(6)}$.

In vivo experimental models may help elucidate this drug effects on neoplastic development, especially with information about effective dose, toxicity and adverse effects. Healthy dogs submitted to thalidomide administration in doses of 43,200 or $1,000 \mathrm{mg} / \mathrm{kg} / \mathrm{day}$ did not present systemic toxicity or significant alterations in clinical parameters ${ }^{(15)}$. However, the action of thalidomide requires speciesdependent metabolic activation and its effects are directly related to the administered dose ${ }^{(1,2)}$. Thus, the objective of this study was to assess the effect of thalidomide on the hematological parameters of the $4 \mathrm{T1}$ murine mammary carcinoma.

For the conduction of the study, 14 female Balb/c mice were used, aged 7 to 8 weeks $(25 \mathrm{~g})$, from Centro de Bioterismo da Universidade Federal de Minas Gerais (CEBIO/UFMG). All procedures were approved by the Ethics Committee on Animal

First submission on 25/08/13; last submission on25/08/13; accepted for publication on 26/09/13; published on 20/02/14

1. Biomedicine graduate; master's student.

2. Doctorate in Pathology; professor.

3. Master's degree in Pathology; doctoral student in Pathology

4. Master's degree in Pharmacology; doctoral student in Pharmacology.

5. Doctorate in Molecular Biology; assistant professor.

6. Doctorate in Pathology; full professor.

7. Doctorate; assistant professor. 
Research (CETEA) at Instituto de Ciências Biológicas (ICB) of UFMG, under protocol no. 201/09.

The murine mammary carcinoma cells (4T1 cell line), acquired from the American Type Culture Collection (ATCC - CRL2539), were cultured according to the manufacturers' instructions. Using Neubauer counting chamber, suspension cell density was determined and corrected to $2.5 \times 10^{6}$ cells $/ 100 \mu \mathrm{l}$, volume that was inoculated into the posterior left flank of all animals to obtain solid tumors ${ }^{(14)}$. All procedures were carried out at the Laboratory of Antitumor Substances, Pharmacology Department of ICB/UFMG.

In the fifth day after inoculation, the animals were divided into two groups daily treated, during seven days, by gavage (orogastric tube):

- control group - $0.9 \%$ saline (500 $\mu \mathrm{l})$;

- treatment group $-150 \mathrm{mg} / \mathrm{kg}(3.5 \mathrm{mg} / 100 \mu \mathrm{ll})$ thalidomide.

After the seventh day of treatment, the animals were euthanized by anesthetic overdose.

For the assessment of tumor growth, measurements were taken every 48 hours, using a caliper. Tumor volume (V) was expressed in $\mathrm{mm}^{3}\left(\mathrm{~V}=\mathrm{a} \times \mathrm{b}^{2} / 2\right)^{(7)}$. During the experimental period, animals' weight was also measured. Blood samples were collected at euthanasia in tubes containing 10\% ethylenediamine tetraacetic acid (EDTA) for the conduction of complete blood count in an automated analyzer ABX Pentra 60. After collection, blood smears were prepared and stained by the May-Grünwald-Giemsa technique for differential count of leukocytes, expressed in percentage, under an optical microscope Olympus BX50, at magnification $\times 40$.

Results were presented as means \pm standard deviation of the mean (SDM). Comparison between both groups was made by using Student's t-test. Results were considered significant for $p<0.05$. The statistical program used was GraphPad Prism 4.0.

Lower growth was observed in the animals treated with thalidomide than in the control group after the sixth day posttumor inoculation $(\phi>0.05)$. Tumor volume analysis after necropsy showed significant reduction in the treatment group $\left(0.147 \pm 0.087 \mathrm{~mm}^{3}\right)$ compared with the control group $(0.269$ $\left.\pm 0.087 \mathrm{~mm}^{3}\right)(p>0.5)$. Tumor weight analysis demonstrated significant reduction in the treatment group $(0.21 \pm 0.07 \mathrm{~g})$ compared with the control group $(0.29 \pm 0.04 \mathrm{~g})(\phi>0.5)$, confirming the effect of thalidomide in tumor volume reduction.

Administration of thalidomide during seven days from the fifth day of inoculation did not cause sedation or altered motor activity of animals. However, the group treated with thalidomide presented a $10 \%$ reduction in body weight $(23 \pm 0.68$ and $21 \pm 1.2$, control and treatment group, respectively) $(\phi<0.05)$.
The hematological profile of mice treated with thalidomide revealed a significant increase in the total number of leukocytes (leukocytosis) and platelets (thrombocytosis) in relation to the control group $(p<0.05)$. The erythrogram (erythrocytes, hemoglobin and mean corpuscular volume [MCV]) and the leukocyte differential count did not indicate statistically different values among the studied groups (Table).

TABLE - Hematological values of Balb/c mice inoculated with the experimental tumor 4T1 submitted to treatment with oral thalidomide $(150 \mathrm{mg} / \mathrm{kg} \mathrm{lw})$

\begin{tabular}{|c|c|c|}
\hline & $150 \mathrm{mg} / \mathrm{kg} \mathrm{lw}$ & Control group \\
\hline Erythrocytes $\left(\mathrm{mm}^{3}\right)$ & 8.84 & 8.41 \\
\hline Hematocrit (\%) & 39.5 & 37.6 \\
\hline Hemoglobin $(\mathrm{g} / \mathrm{dl})$ & 15.5 & 14.1 \\
\hline MCV (fl) & 45 & 45 \\
\hline Platelets $\left(\mathrm{mm}^{3}\right)$ & $591,000 *$ & 324,000 \\
\hline Total leukocyte counts $\left(\mathrm{mm}^{3}\right)$ & $23,100^{*}$ & 9,100 \\
\hline Lymphocytes (\%) & 72 & 69.4 \\
\hline Segmented neutrophils (\%) & 23.7 & 27.9 \\
\hline Monocytes (\%) & 2.9 & 0.9 \\
\hline Band neutrophils (\%) & 1.9 & 1.6 \\
\hline Blasts (\%) & 0.2 & 0.1 \\
\hline
\end{tabular}

MCV: mean corpuscular volume; lw: live weight; $* 0.05$, compared with the control group.

The antitumor effect of thalidomide has been mainly associated with its antiangiogenic property ${ }^{(5)}$, although the immunomodulatory effect of this drug has also been described for control of some neoplasms ${ }^{(4,12)}$. The data obtained in this experiment demonstrated that thalidomide inhibited tumor growth of the 4T1 mammary carcinoma, similarly to what was described by Israyelyan et al. ${ }^{(11)}$. Reduction of neoplastic growth is apparently associated with modulation of the tumor immune response ${ }^{(2,12)}$.

Among the immunomodulatory effects of thalidomide, activation of inflammatory cells is demonstrated as an effective mechanism of action for the control of neoplasms in humans and experimental models ${ }^{(4,12)}$. Increased number of natural killer (NK) cells and cytotoxic T lymphocytes is described in different proposals for antineoplastic therapy with thalidomide ${ }^{(12,17)}$. The increased number of circulating leukocytes may be an important event in this immunomodulatory response of thalidomide. It must be considered a relevant clinical parameter in the adoption of this therapy.

Besides antitumor effects, the side effects of thalidomide are well described. They include peripheral neuropathy, constipation, thrombotic events, and neutropenia ${ }^{(6)}$. Our data demonstrated a 
significant increase in the number of total platelets and leukocytes in the group treated with thalidomide.

Current results are contradictory as to the increased platelet count in thalidomide-treated patients ${ }^{(8,10)}$. However, the occurrence of thrombotic events in these patients is common and has been associated with the increase and activation of platelets and procoagulant factors ${ }^{(0,10)}$.
Although thalidomide is associated with the improvement of cytopenia, in neoplastic and non-neoplastic conditions, and its toxicity is $\operatorname{low}^{(3,8,16)}$, it must be used with caution in the oncologic practice in order to minimize secondary effects.

Our results suggest that thalidomide treatment increases the number of circulating leukocytes in the 4T1 murine mammary carcinoma. This response was followed by a decrease in tumor growth.

\section{RESUMO}

O objetivo deste trabalbo foi avaliar o efeito do tratamento com talidomida no carcinoma mamário murino 4T1. Após a suspensão de células 4T1, estas foram inoculadas no flanco esquerdo para obtenção de tumor sólido. Depois de cinco dias de inoculação, o grupo tratado recebeu, por via oral, $150 \mathrm{mg} / \mathrm{kg}$ de talidomida por sete dias. Os tumores foram mensurados a cada 48 horas e ao final do experimento. Sangue total foi coletado para análise hematológica. Os resultados sugerem que a terapêutica com talidomida aumenta o número de leucócitos circulantes no carcinoma mamário murino 4T1. Essa resposta foi acompanhada de uma diminuição do crescimento tumoral.

Unitermos: camundongo; neoplasia; tumor 4T1; talidomida.

\section{REFERENCES}

1. BAUER, K. S.; DIXON, S. C.; FIGG, W. D. Inhibition of angiogenesis by thalidomide requires metabolic activation, which is species-dependent. Biochem Pharmacol, v. 55, n. 11, p. 1827-34, 1998.

2. BELO, A. V. et al. Differential effects of thalidomide on angiogenesis and tumor growth in mice. Inflammation, v. 25, n. 2, p. 91-6, 2001.

3. BOUSCARY, D. et al. A non-randomised dose-escalating phase II study of thalidomide for the treatment of patients with low-risk myelodyplastic syndromes: the Thal-SMD-2000 trial of the Groupe Français des Myélodysplasies. Br J Haematol, v. 131, n. 5, p. 609-18, 2005.

4. DAVIES, F. E. et al. Thalidomide and immunomodulatory derivatives augment natural killer cell cytotoxicity in multiple myeloma. Blood, v. 98, n. 1, p. 210-6, 2001.

5. D'AMATO, R. J. et al. Thalidomide is an inhibitor of angiogenesis. Proc Natl Acad Sci, v. 91, n. 9, p. 4082-5, 1994.

6. ELEUTHERAKIS-PAPAIAKOVOU, V.; BAMIAS, A.; DIMOPOULOS, M. A. Thalidomide in cancer medicine.Ann Oncol, v. 15, n. 8, p. 1151-60, 2004.

7. FULZELE, S. V. et al. Inhalation delivery and anti-tumor activity of celecoxib in human orthotopic non-small cell lung cancer xenograft model. Pharm Res, v. 23, n. 9, p. 2094-2106, 2006.

8. HATTORI, Y. et al. Prospective study of combination therapy with lowdose thalidomide plus prednisolone ameliorating cytopenia in primary myelofibrosis. Int J Hematol, v. 93, n. 1, p. 129-31, 2011.
9. HOSHI, A. et al. Activation of coagulation by a thalidomide-based regimen. Blood Coagul Fribrinolysis, v. 22, n. 6, p. 523-40, 2011.

10. IPEK, Y. et al. Thrombotic complications in multiple myeloma: a report of three cases and review of the literature. J Thromb Thrombolysis, v. 33, n. 2, p. 197-201, 2012.

11. ISRAYELYAN, A. et al. Thalidomide delayed the ability of 4T1 cells to amass into tumors in Balb/c mice.Immunopharmacol Immunotoxicol, v. 34, n. 3, p. 408-12, 2012

12. KAWAMATA, A. et al. Thalidomide suppresses melanoma growth by activating natural killer cells in mice. Oncol Rep, v. 16, n. 6, p. 1231-6, 2006.

13. MOREIRA, A. L. et al. Thalidomide exerts its inhibitory action on tumor necrosis factor $\alpha$ by enhancing mRNA degradation. J Exp Med, v. 177, n. 6, p. 1675-80, 1993.

14. PULASKI, B. A.; OSTRAND-ROSENBERG, S. Mouse 4T1 breast tumor model. Curr Protoc Immunol, v. 20, n. 2, 2001.

15. TEO, S. K. et al. Safety profile of thalidomide after 53 weeks of oral administration in beagle dogs. Toxicol Sci, v. 59, n. 1, p. 160-8, 2001.

16. THOMAS, D. A. et al. Thalidomide therapy for myelofibrosis with myeloid metaplasia. Cancer, v. 106, n. 9, p. 1974-84. 2006.

17. YANG, Y.; DU, G.; LIN, H. Experimental study of thalidomide for treatment of murine hepatocellular carcinoma. J First Mil Med Univ, v. 25 , n. 8 , p. $925-8,2005$.

\section{MAILING ADDRESS}

Enio Ferreira

Instituto de Ciências Biológicas - Laboratório de Patologia Comparada (LPC); Av. Antônio Carlos, 6.627, bloco C3, sala 166 - Pampulha; CEP: 31270-901; Belo Horizonte-MG - Brazil; e-mail: enioferreira@icb.ufmg.br. 